\title{
Uwarunkowania i skala redukcji zanieczyszczeń gazowych w krajowych elektrowniach zawodowych
}

Charakterystyczną cechą funkcjonowania krajowej elektroenergetyki w latach 90 . jest istotne ograniczenie presji na środowisko, zwłaszcza w zakresie emisji zanieczyszczeń gazowych (Luchter 1996). Skala tego zjawiska jest szczególnie duża w przypadku redukcji dwutlenku siarki, pomimo zachowania w sektorze monokultury paliw stałych oraz pojawienia się od 1994 r. progresywnej tendencji w produkcji energii elektrycznej. Analiza relacji i uwarunkowań między przemysłem a środowiskiem należy do tradycyjnego, nie tracącego na aktualności kierunku badawczego geografii przemysłu (Kortus 1986, Wieloński 2000).

Celem niniejszego opracowania jest przedstawienie skali redukcji zanieczyszczeń gazowych oraz dynamiki zmian zachodzących w relacjach elektroenergetyka a środowisko. Zidentyfikowano także i określono wpływ istotnych czynników na przebieg tego procesu w czasie i w przestrzeni.

Do realizacji tak sformułowanego celu badawczego wykorzystano dane statystyczne o potencjale produkcyjnym elektroenergetyki, parametrach jakościowych zużywanego paliwa oraz wielkości emisji zanieczyszczeń zawarte w kolejnych tomach Statystyki Elektroenergetyki Polskiej i Emitora. Publikacje te zostały wydane w latach 1990-1999 przez Agencje Rynku Energii S.A. w Warszawie.

\section{Geneza i uwarunkowania procesu redukcji zanieczyszczeń gazowych}

W krajach europejskich o gospodarce rynkowej skuteczna ochrona środowiska stała się już w latach 70. podstawowym warunkiem i nieodłącznym atrybutem wszelkich przedsięwzięć związanych z pozyskiwaniem, przetwarzaniem, transportem i użytkowaniem energii. W sposób szczególny znalazło to wyraz w obligatoryjnej dla energetyki dyrektywie wydanej w 1988 r. przez ówczesną Europejską Wspólnotę Gospodarczą (88/609/EWG) w sprawie ograniczenia emisji zanieczyszczeń do atmosfery z dużych obiektów energetycznych spalających paliwa (Wykaz standardów 1994).

W Polsce dopiero na początku lat 90 . wraz z realizacją przekształceń strukturalnych w elektroenergetyce $\mathrm{i}$ zerwaniem $\mathrm{z}$ centralistycznym modelem jej organizacji rozpoczęto przykładać należyta uwagę do ekologicznych problemów funkcjonowania elektrowni cieplnych. Radykalna zmiana stanowiska sektora w kwestii ochrony środowiska leży u podstaw rozpoczętego w 1989 r. procesu systemowej transformacji polskiej gospodarki 
oraz wiąże się z zainicjowaniem integracji z krajami rynkowymi, czego wyrazem było podpisanie w 1991 r. układu stowarzyszeniowego między Rzeczypospolitą Polską a Unią Europejską. W tej sytuacji wprowadzenie norm ochrony środowiska porównywalnych z prawem unijnym stało się jednym z kluczowych zagadnień warunkujących przystąpienie Polski do tej organizacji.

Polski rząd zobligowany jest również do przestrzegania międzynarodowych konwencji i towarzyszących im protokołów w sprawie ograniczenia emisji transgranicznych zanieczyszczeń, a szczególnie zaleceń II Protokołu Siarkowego (1994), II Protokołu Azotowego (1999) i Protokołu z Kioto (1997) odnośnie gazów cieplarnianych. Zobowiązania ekologiczne wynikające $\mathrm{z}$ tych międzynarodowych porozumień administracja rządowa przetransponowała na limity emisji obowiązujące w konkretnych sektorach gospodarki oraz na różnorakie mechanizmy ekonomiczne (np. opłaty za korzystanie ze środowiska) wspierające realizację przyjętych programów. Wśród sektorów gospodarki o największej presji na środowisko znajduje się elektroenergetyka zawodowa, na którą w latach 90. przypadało około $50-54 \%$ krajowej emisji dwutlenku siarki, 28-34\% tlenków azotu i 36-43\% dwutlenku węgla.

Do końca lat 80. zagadnienia ochrony środowiska w programach rozwoju krajowej elektroenergetyki traktowano postulatywnie, jako jedno $\mathrm{z}$ tych działań, które nie powinno być zaniedbywane. W praktyce nie przywiązywano większej wagi do tego problemu, o czym świadczy między innymi fakt nie uwzględniania zawartości siarki w węglu kamiennym przy konstruowaniu cenników na to paliwo dla elektroenergetyki. Natomiast duże elektrownie o mocy powyżej $1000 \mathrm{MW}$ spalające paliwo stałe wyposażono w wysokie kominy, co zmniejszyło wprawdzie wpływ wyprowadzanego dwutlenku siarki na jakość powietrza w okolicy, ale zwiększyło przestrzenny zasięg jego szkodliwego działania przez zakwaszanie środowiska.

Proces redukcji zanieczyszczeń gazowych w elektrowniach zawodowych rozpoczął się w 1990 r., kiedy to wprowadzono po raz pierwszy zaostrzone normy emisji zanieczyszczeń gazowych wraz z progresywnymi opłatami za korzystanie ze środowiska. Była to próba adoptowania zaleceń europejskiego prawa (dyrektywa 88/609/EWG) w sprawie ograniczenia emisji z dużych obiektów energetycznych do polskich warunków społecznogospodarczych. Jednakże dopiero w 1996 r., po podpisaniu przez rząd polski II Protokołu Siarkowego przyjęto do realizacji w sektorze elektroenergetycznym program redukcji dwutlenku siarki, opracowany przez Polskie Sieci Elektroenergetyczne S.A. (Poręba, Gajda, Burakowski 1997). Zakłada on obniżenie emisji dwutlenku siarki w elektroenergetyce o $35 \%$ w stosunku do 1989 r., tak aby w 2010 r. wielkość emisji w elektrowniach wyniosła 700 tys. ton, tj. około 50\% krajowego wolumenu ustalonego w II Protokole Siarkowym.

Istotnym bodźcem do przyspieszenie ekologicznej modernizacji elektrowni i prawnym usankcjonowaniem tego procesu stała się ustawa Prawo Energetyczne (1997) oraz opracowane zgodnie z nią Założenia Polityki Energetycznej do 2020 r., gdzie tak jednoznacznie powiązano energetykę i środowisko. Od 1998 r. zaczęły obowiązywać w sektorze nowe, bardziej rygorystyczne w stosunku do 1990 r. limity emisji zanieczyszczeń gazowych, których poziom zależy od daty oddania do eksploatacji elektrowni (Gajda, Barc 1999).

Tak więc na zainicjowanie i kontynuację procesu redukcji zanieczyszczeń gazowych w elektroenergetyce wpłynęły zarówno uwarunkowania zewnętrzne (międzynarodowe) jak i wewnętrzne (krajowe). Dyscyplinujące dla elektrowni są przede wszystkim sukcesywnie 
wprowadzane instrumenty prawne w formie rozporządzeń Ministerstwa Ochrony Środowiska Leśnictwa i Zasobów Naturalnych, które obok poziomu limitów zróźnicowanych w zależności od źródła emisji i rodzaju użytkowanego paliwa zawierają stawki opłat za korzystanie ze środowiska i składowanie odpadów energetycznych. Wielkość tych opłat w latach 90. ulegała stopniowej podwyżce wraz ze wzrostem inflacji. Na przykład w $2000 \mathrm{r}$. opłaty za emisję zanieczyszczeń gazowych wyniosły: dwutlenek siarki - 0,34 zł/kg, dwutlenek węgla - 0,18 zl/kg, tlenki azotu - 0,34 zł/kg (Dziennik Ustaw nr 110, XII 1999).

\section{Ksztaltowanie się tendencji między produkcją energii elektrycznej, zużyciem paliw a emisją zanieczyszczeń}

Prowadzona przez rząd polski po II wojnie światowej polityka samowystarczalności energetycznej, przy ograniczonych możliwościach finansowych importu paliw węglowodorowych i braku większego zainteresowania hydroenergetyką spowodowało, że energia elektryczna jest generowana w około $97 \%$ w elektrowniach cieplnych, bazujących na węglu kamiennym i brunatnym. Spalanie paliw stałych stwarza szczególne zagrożenie dla środowiska, gdyż właśnie w trakcie tego procesu powstają między innymi szkodliwe związki jak tlenki siarki, azotu, węgla. Nieszkodliwy dla zdrowia dwutlenek węgla intensyfikuje efekt cieplarniany.

Porównanie przebiegu tendencji w zakresie produkcji energii elektrycznej, zużycia paliw i emisji zanieczyszczeń do atmosfery potwierdza wcześniejsze stwierdzenia o pogłębianiu się w latach 1971-1989 procesu szkodliwego oddziaływania elektroenergetyki na środowisko (ryc. 1). W tym okresie rosnącej dynamice produkcji towarzyszyła porównywalna dynamika wzrostu emisji dwutlenku siarki, przy niewielkich wahaniach tempa emisji pyłów, przy czym zjawisko to szczególnie nasiliło się w latach 80 . Było to konsekwencją zwiększenia produkcji w oparciu o wysoko zasiarczony węgiel kamienny $(1,5-2,5 \%$ siarki) w elektrowniach Jaworzno III i Połaniec oraz uruchomienia el. Bełchatów. Bazuje ona wprawdzie na węglu brunatnym o niskim stopniu zasiarczenia (przeciętnie 0,58\%) lecz przy rocznym zużyciu rzędu $32 \mathrm{mln}$ ton emisja siarki do atmosfery odgrywa kluczową rolę w krajowej elektroenergetyce. Sytuacja uległa radykalnej zmianie w latach 90., a wyraźną cezurą czasowa jest rok 1990, kiedy to nastąpiło „odsprzęglenie” produkcji energii elektrycznej i częściowo zużycia paliw od wielkości emisji dwutlenku siarki. Ten korzystny trend rozwarcia nożyc między dynamiką produkcji a dynamiką emisji zanieczyszczeń był kontynuowany do końca lat 90. 


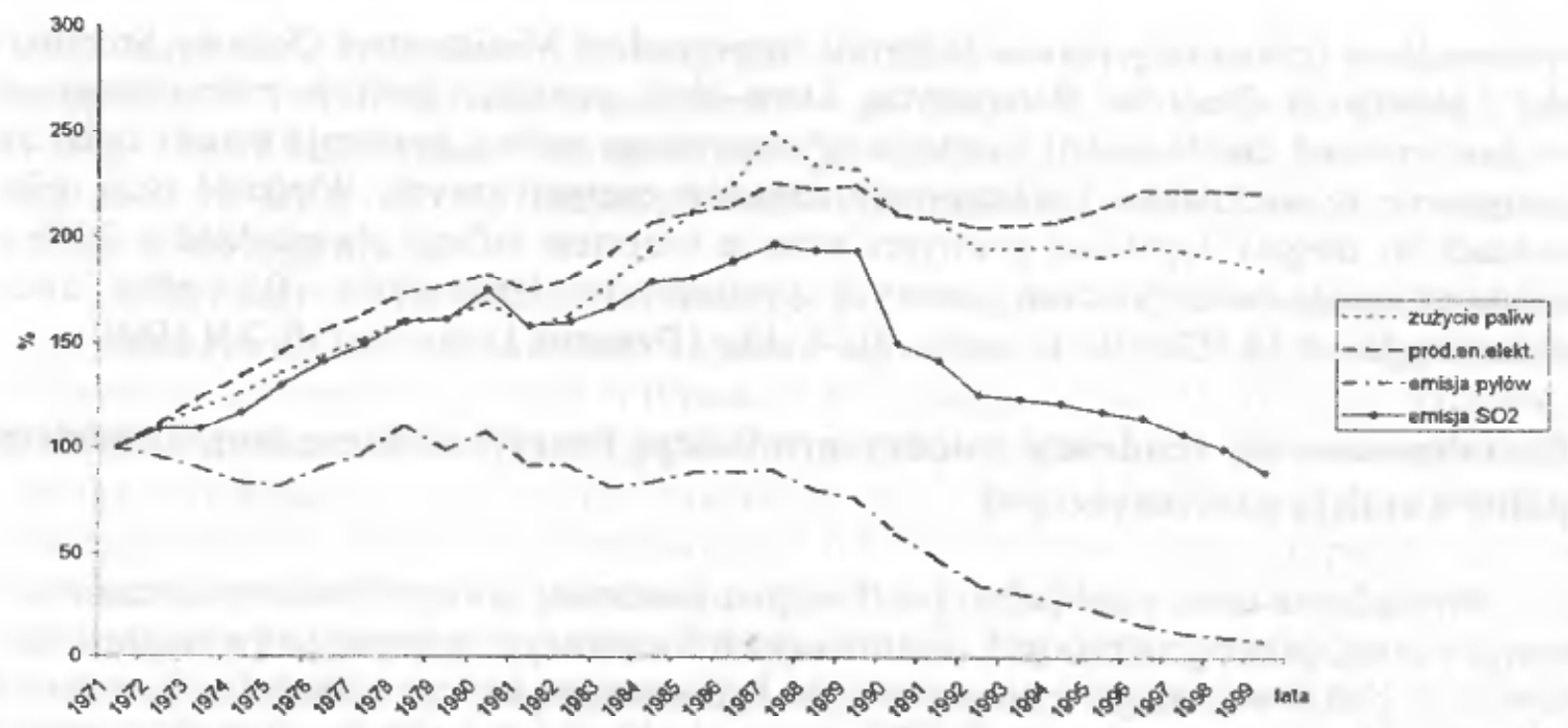

Źródło: Opracowano na podstawie Statystyki Elektroenergetyki Polskiej 1975-1999. ARE, W-wa

Ryc. 1. Dynamika emisji zanieczyszczeń w elektrowniach zawodowych na tle zużycia paliwa i produkcji energii elektrycznej $(1971=100)$

Kształtowanie się tendencji w zakresie emisji tlenków azotu i dwutlenku węgla w elektroenergetyce można jedynie prześledzić dla ostatniej dekady XX wieku, ze względu na brak wcześniejszych danych statystycznych. Przebieg wykresów dynamiki świadczy o występowaniu korzystnych relacji między wielkością produkcji a emisją zanieczyszczeń gazowych, z wyjątkiem dwutlenku węgla. Utrzymywanie się na prawie tym samym poziomie dynamiki emisji tego gazu jest konsekwencją zachowania w elektroenergetyce dominacji paliw stałych (ryc. 2).

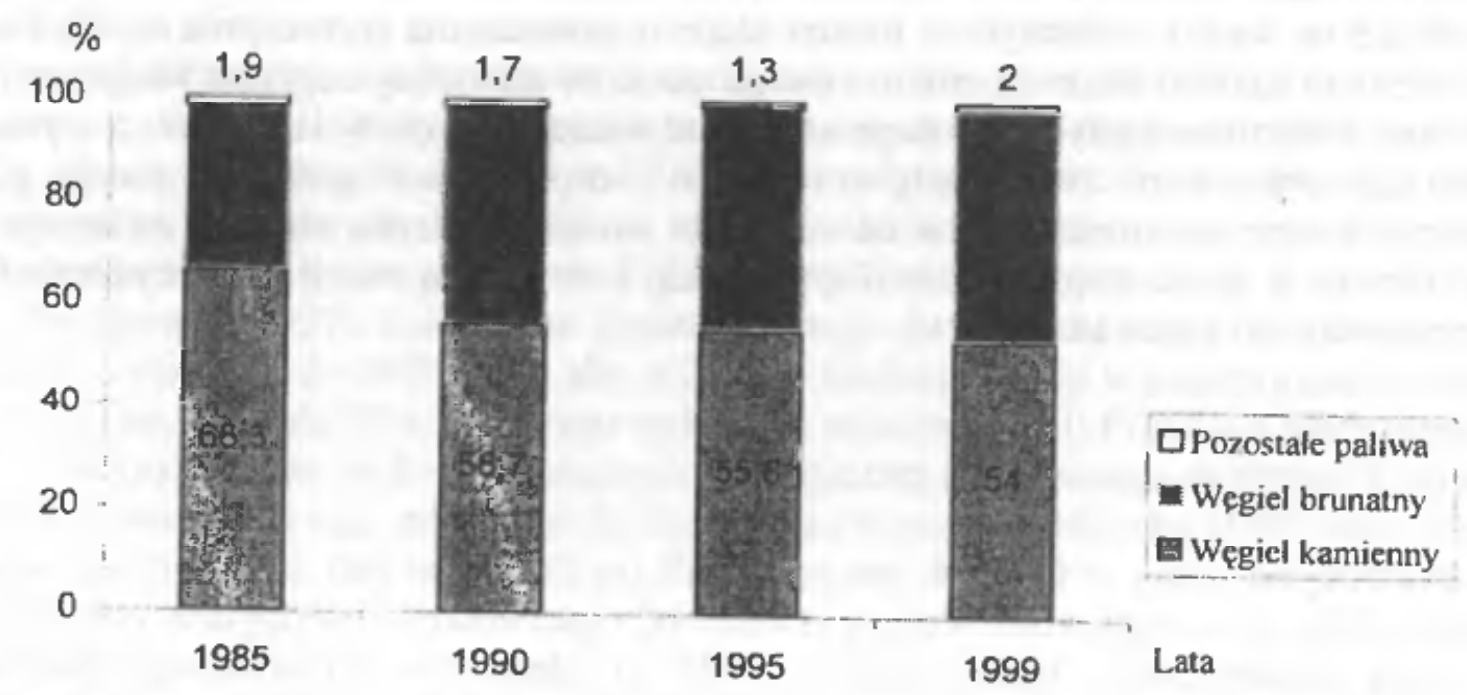

Źródło: Opracowano na podstawie Statystyki Elektroenergetyki Polskiej z lat 1990-1999, ARE, W-wa

Ryc. 2. Struktura zużycia paliw na produkcję energii elektrycznej w elektrowniach zawodowych 


\section{Skala redukcji zanieczyszczeń gazowych, czynniki warunkujące ten proces}

W okresie 1991-1999 wyraźnemu ograniczeniu uległa presja elektroenergetyki na środowisko, o czym świadczy znacząca skala redukcji zanieczyszczeń gazowych. Podczas gdy produkcja energii elektrycznej spadła w tym czasie zaledwie o $2 \%$, a zużycie paliwa o około $20 \%$, to ilość wyemitowanej siarki zmniejszyła się o ponad $54 \%$ a tlenków azotu o $36 \%$ (Tabela 1).

Tabela 1. Zużycie paliw, produkcja energii elektrycznej i emisja zanieczyszczeń gazowych z elektrowni zawodowych cieplnych

\begin{tabular}{|c|c|c|c|c|c|c|c|c|c|c|}
\hline \multirow[b]{2}{*}{ Lata } & \multicolumn{2}{|c|}{ Zużycie paliw } & \multicolumn{2}{|c|}{$\begin{array}{l}\text { Produkcja energii } \\
\text { elektrycznej }\end{array}$} & \multicolumn{2}{|c|}{ Emisja $\mathrm{SO}_{2}$} & \multicolumn{2}{|c|}{ Emisja $\mathrm{NO}_{\mathrm{x}}$} & \multicolumn{2}{|c|}{ Emisja $\mathrm{CO}_{2}$} \\
\hline & $\min \mathrm{t}$ & $\begin{array}{l}\text { Wskażnik } \\
\text { dynamiki } \\
1989=100\end{array}$ & $\begin{array}{l}\text { mld } \\
\mathrm{kWh}\end{array}$ & $\begin{array}{l}\text { Wskażnik } \\
\text { dynamiki } \\
1989=100\end{array}$ & tys.t & $\begin{array}{l}\text { Wskażnik } \\
\text { dynamiki } \\
\text { 1989=100 }\end{array}$ & tys. $t$ & $\begin{array}{l}\text { Wskażnik } \\
\text { dynamiki } \\
1991=100\end{array}$ & $\mathrm{mln} t$ & $\begin{array}{l}\text { Wskażnik } \\
\text { dynamiki } \\
1990=100\end{array}$ \\
\hline 1989 & 127,4 & .100 & 133,2 & 100 & 2018 & 100 & & & & \\
\hline 1990 & 115,7 & 90,8 & 124,9 & 93,8 & 1560 & 77,3 & & & 150,3 & 100 \\
\hline 1991 & 113,8 & 89,3 & 123,4 & 92,6 & 1477 & 73,2 & 394,1 & 100 & 148,5 & 98,8 \\
\hline 1992 & $106, .8$ & 83,8 & 121 & 90,8 & 1311 & 65 & 370,2 & 93,9 & 140,4 & 93,4 \\
\hline 1993 & 107,1 & 84,1 & 121,8 & 91,4 & 1283 & 63,6 & 372,9 & 94,6 & 134,4 & 89,4 \\
\hline 1994 & 107,5 & 84,4 & 123.1 & 92,4 & 1272 & 63 & 377,8 & 95,9 & 145,3 & 96,7 \\
\hline 1995 & 104,9 & 82,3 & 126,8 & 95,2 & 1222 & 60,5 & 380.2 & 96,5 & 147,1 & 97.9 \\
\hline 1996 & 107,7 & 84,5 & 131,1 & 98,4 & 1197 & 59,3 & 366,9 & 93,1 & 156,3 & 104 \\
\hline 1997 & 106,1 & 83,3 & 131 & 98,3 & 1110 & 55 & 317,2 & 80,5 & 153,1 & 101,9 \\
\hline 1998 & 103,9 & 81,5 & 131 & 98,3 & 1038 & 51,4 & 271,2 & 68,8 & 144,3 & 96 \\
\hline 1999 & 101,5 & 79,7 & 130,6 & 98 & 920 & 45,6 & 251,5 & 63,8 & 145,6 & 96,9 \\
\hline
\end{tabular}

Źródło: Opracowano na podstawie Statystyki Elektroenergetyki Polskiej z lat 1989-1999, ARE, Warszawa

Emitor 1993-1999, ARE

Postęp ekologiczny jaki dokonał się w sektorze elektroenergetyki najlepiej oddają wskaźniki emisji gazów (Tabela 2). Emisja dwutlenku siarki na wytworzoną jednostkę energii elektrycznej w energetyce zawodowej ogółem zmniejszyła się w latach 1994-1999 z $8,7 \mathrm{~g} / \mathrm{kWh}$ do $6,0 \mathrm{~g} / \mathrm{kWh}$, przy czym większy spadek wartości wskaźnika zanotowano w elektrowniach spalających węgiel brunatny (o $3,4 \mathrm{~g} / \mathrm{kWh}$ ) aniżeli w elektrowniach bazujących na węglu kamiennym (o 2,1 g/kWh). Pomimo tego zachowana została prawie dwukrotna różnica w poziomie wskaźnika, na korzyść elektrowni użytkujących węgiel kamienny ze względu na jego wyższą wartość opałową (Tabela 3). Dlatego teź między innymi zużycie paliwa rzeczywistego w elektrowniach na węgiel kamienny kształtuje się na poziomie $406 \mathrm{~g} / \mathrm{kWh}$, podczas gdy w elektrowniach na węglu brunatnym wynosi aż $1173 \mathrm{~g} / \mathrm{kWh}$ (dane z 1999 r.). 
Tabela 2. Wskaźniki emisji gazów w stosunku do produkcji energii elektrycznej w latach 1994-1999

\begin{tabular}{|c|c|c|c|}
\hline \multirow{2}{*}{ Lata } & \multicolumn{3}{|c|}{ Wskaźniki emisji w $\mathrm{g} / \mathrm{kWh}$} \\
\cline { 2 - 4 } & SO $_{2}$ & NO $_{\mathrm{x}}$ & $\mathrm{CO}_{2}$ \\
\hline \multicolumn{4}{|c|}{ Elektrownie zawodowe ogólem } \\
\hline 1994 & 8,7 & - & - \\
1995 & 8,1 & - & - \\
1996 & 7,6 & 2,3 & 985,8 \\
1997 & 7,1 & 2,0 & 977,3 \\
1998 & 6,7 & 1,8 & 929,2 \\
1999 & 6,0 & 1,6 & 948,7 \\
\hline \multicolumn{4}{|c|}{ Elektrownie na weglu brunatnym } \\
\hline 1994 & 11,9 & - & - \\
1995 & 10,6 & - & - \\
1996 & 9,8 & 1,7 & 1282,3 \\
1997 & 9,6 & 1,6 & 1263,5 \\
1998 & 9,6 & 1,6 & 1114,2 \\
1999 & 8,5 & 1,5 & 1171,5 \\
\hline \multicolumn{4}{|c|}{ Elektrownie na węglu kamiennym } \\
\hline 1994 & 6,8 & - & - \\
1995 & 6,7 & - & - \\
1996 & 6,4 & 2,6 & 831,2 \\
1997 & 5,8 & 2,2 & 826,3 \\
1998 & 5,1 & 1,8 & 823,7 \\
1999 & 4,7 & 1,7 & 826,7 \\
\hline
\end{tabular}

Źródło: opracowano na podstawie Emitora 1994-2000, ARE, W-wa

W zakresie tlenków azotu odnotowano korzystny spadek wartości emisji wskaźnika z 2,3 g/kWh w $1994 \mathrm{r}$. do 1,6 g/kWh w 1999r. Natomiast w przypadku dwutlenku węgla wartości wskaźnika w analizowanym okresie uległy niewielkiej redukcji, głownie z powodu poprawy sprawności wytwarzania energii elektrycznej z 34,9\% do 35,6\%.

Dezagregacja krajowych wskaźników emisji dwutlenku siarki pozwoliła na identyfikację skali zjawiska i określenie jego dysproporcji na poziomie poszczególnych, dużych elektrowni. Jak wynika z ryc. 4 elektrownie zawodowe tworzą zróżnicowaną zbiorowość pod tym względem pomimo zachodzących pozytywnych zmian. Generalnie w latach 1989-1998 wraz ze zmniejszeniem się wartości wskaźników uległa redukcji rozpiętość między maksymalną a minimalną jego wartością, tj., z $21 \mathrm{~g} / \mathrm{kWh}$ wytworzonej energii elektrycznej do $3,4 \mathrm{~g} / \mathrm{kWh}$, co ilustruje histogram dynamiczny (ryc. 3). W tym rozkładzie najkorzystniej przedstawia się el. Opole, która spełnia najbardziej rygorystyczne wymogi środowiskowe określone dla nowych obiektów, oddanych do eksploatacji po 1993 r., które odpowiadają regulacjom obowiązującym w krajach Unii Europejskiej. W przypadku elektrowni na węglu brunatnym analizowane róźnice między wskaźnikami nie były tak duże. W niewielkim stopniu uległy obniżeniu z $12 \mathrm{~g} / \mathrm{kWh}$ w 1989 r do $9.3 \mathrm{~g} / \mathrm{kWh}$ w $1998 \mathrm{r}$., co należy wiązać z bardziej wyrównaną zawartością siarki w eksploatowanych złożach (ryc. 4). Dobra pozycja elektrowni Adamów na tle pozostałych wynika z użytkowania węgla o najniższym zasiarczeniu rzędu $0,27 \%$. 


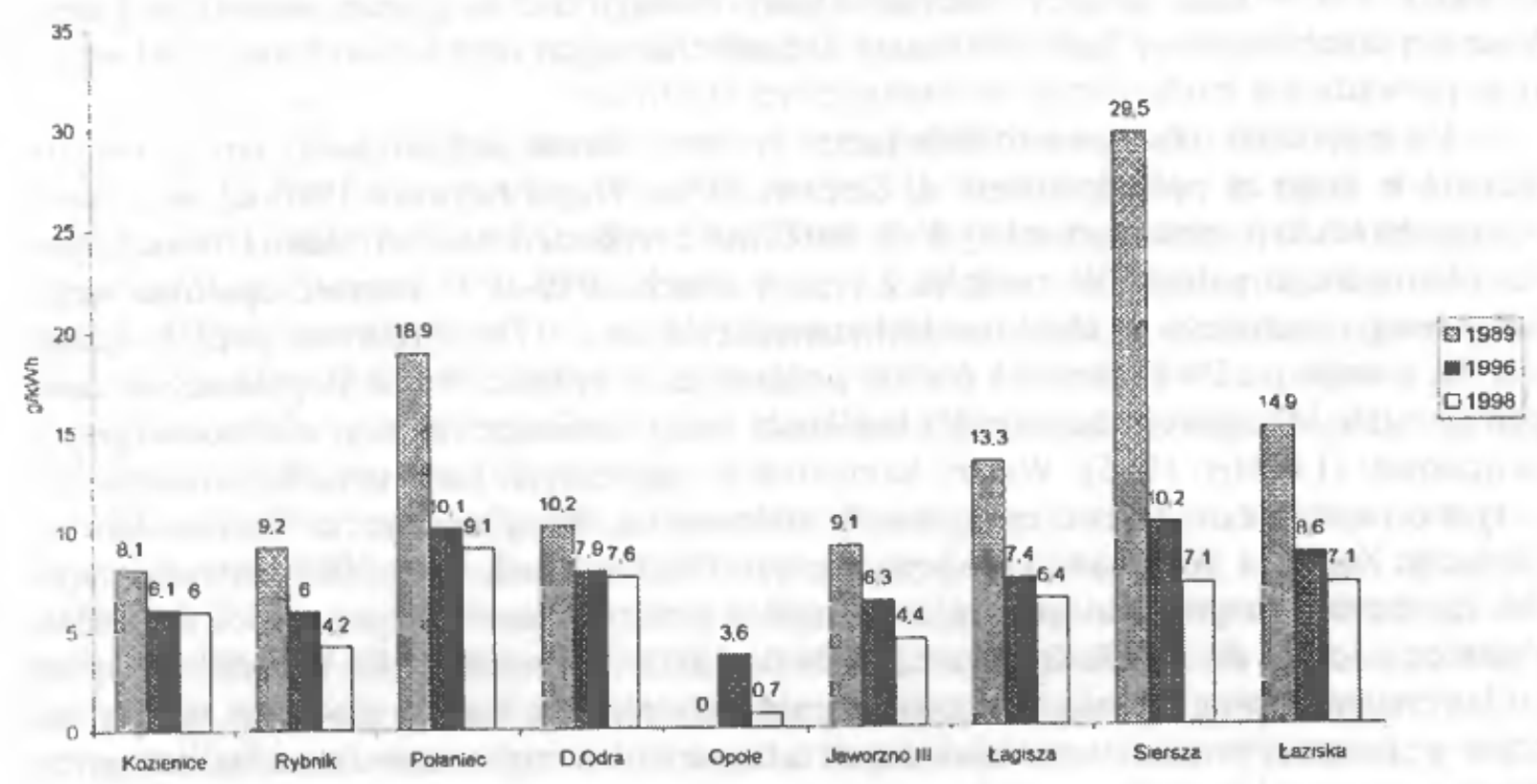

Źródlo: Opracowano na podstawie Emitora z lat 1990-1999, ARE, W-wa

Ryc. 3. Jednostkowa emisja $\mathrm{SO}_{2}$ w elektrowniach na węgiel kamienny o mocy powyżej $700 \mathrm{MW}$ w latach 1989, 1996, 1998

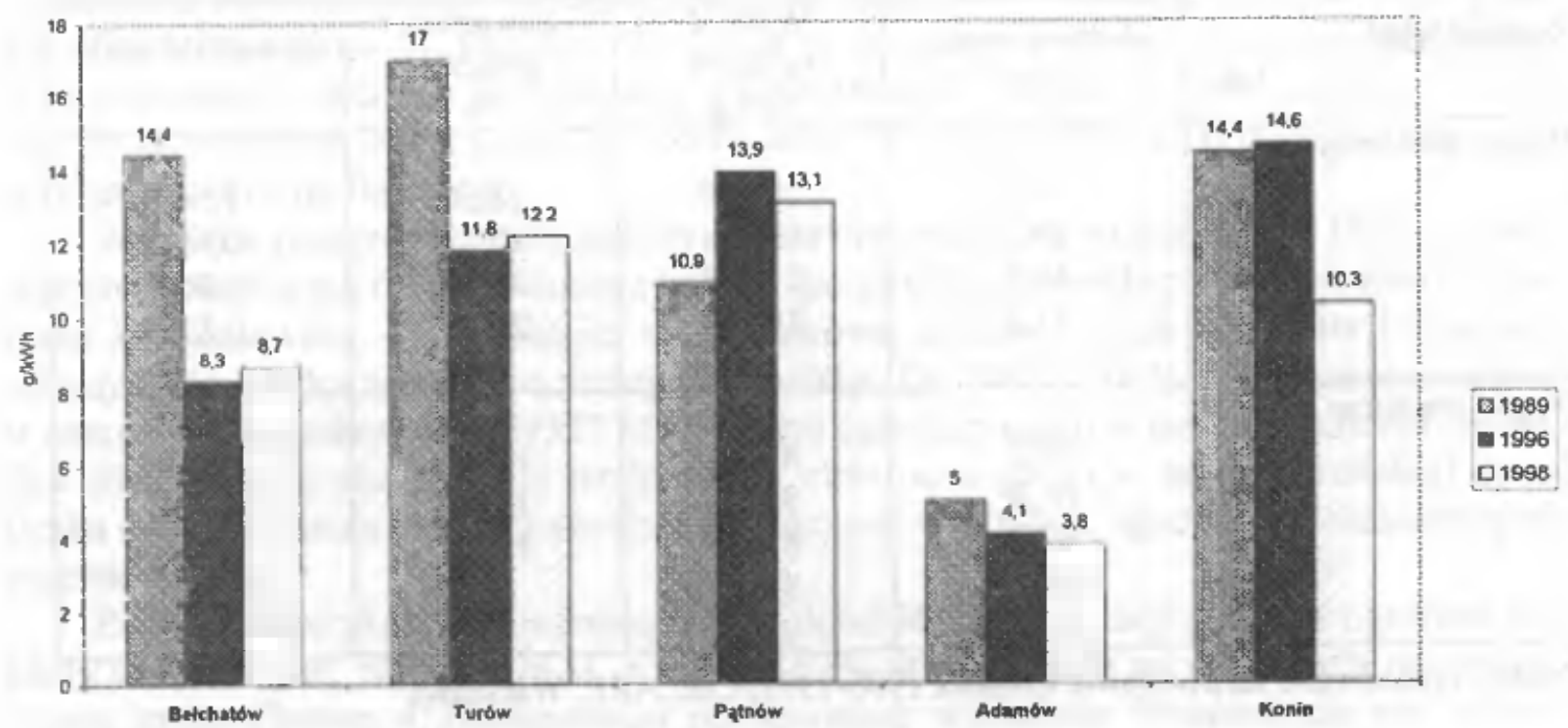

Źródło: Opracowano na podstawie Emitora z lat 1990-1999, ARE, W-wa

Ryc. 4. Jednostkowa emisja $\mathrm{SO}_{2}$ w elektrowniach na węgiel brunatny w latach 1989,1996 , 1998

Proces redukcji zanieczyszczeń gazowych można podzielić na dwie fazy, w zależności od rozwiązań i metod podjętych przez elektroenergetykę w celu sprostania zaostrzonym wymogom ochrony środowiska. Pierwsza faza obejmuje lata 1990-1995, kiedy to istotne obniżenie emisji zanieczyszczeń uzyskano w sposób bezinwestycyjny, metodami organiza- 
cyjnymi. Zaś w fazie drugiej znaczące efekty ekologiczne są przede wszystkim konsekwencją uruchomienia i funkcjonowania kapitałochłonnych urządzeń ochrony środowiska oraz prowadzenia modernizacji technologicznej elektrowni.

Po zniesieniu nakazowo-rozdzielczego systemu obrotu węglem kamiennym, realizowanym w kraju za pośrednictwem d. Centrali Zbytu Węgla (styczeń 1990 r.), w sytuacji jego nadprodukcji, elektrownie uzyskały możliwość wyboru dostawców jak i również jakości oferowanego paliwa. W związku z tym w latach 1989-1995 wartość opałowa węgla kamiennego spalonego w elektrowniach zwiększyła się o $17 \%$, zawartość popiołu spadła o $27 \%$, a siarki o 25\% (Tabela 3). Należy podkreślić, że zróżnicowanie stopnia zasiarczenia paliwa miało kluczowe znaczenie dla wielkości emisji zanieczyszczeń w elektroenergetyce zawodowej (Luchter 1995). Węgiel kamienny o najgorszych parametrach jakościowych, w tym o najwyższym zasiarczeniu, spalały elektrownie zlokalizowane na obszarze Górnośląskiego Zagłębia Węglowego lub jego obrzeżu. Stąd w latach 1989-1995 najwyższy spadek zasiarczenia użytkowanego węgla wystąpił w elektrowniach: Siersza z 2,5\% do $1,03 \%$, Połaniec z $1,66 \%$ do $1,14 \%$, Siersza z $2,52 \%$ do $1,03 \%$, Skawina $1,44 \%$ do $0,99 \%$. Barierą do korzystania z węgla o niższym zasiarczeniu stały się jego koszty. Kopalnie wyszły naprzeciw progresywnemu wzrostowi zapotrzebowaniu na niskozasiarczone paliwo przez stopniowe powiększanie potencjału przetwórczego $\mathrm{w}$ istniejących zakładach wzbogacania węgla i podejmowaniu nowych inwestycji (Luchter 1996).

Tabela 3. Charakterystyka jakościowa paliwa użytkowanego w elektrowniach zawodowych

\begin{tabular}{|lc|c|c|c|c|}
\hline Rodzaje węgli & Lata & $\begin{array}{c}\text { Zużycie węgla } \\
\text { mln t }\end{array}$ & $\begin{array}{c}\text { Wartość } \\
\text { opałowa } \\
\mathrm{kJ} / \mathrm{kg}\end{array}$ & $\begin{array}{c}\text { Zawartość } \\
\text { popiołu } \\
\%\end{array}$ & $\begin{array}{c}\text { Zawartość siarki } \\
\%\end{array}$ \\
\hline Wegiel kamienny & 1989 & 54,3 & 18350 & 28,56 & 1,148 \\
& 1990 & 49,2 & 19000 & 25,59 & 0,965 \\
& 1995 & 42,7 & 21463 & 20,83 & 0,852 \\
& 1999 & 41,2 & 21538 & 20,27 & 0,876 \\
\hline Wegiel brunatny & & & & & \\
& 1989 & 70,5 & 8103 & 12,48 & $.0,661$ \\
& 1990 & 66,4 & 8292 & 11,60 & 0,594 \\
& 1995 & 62,2 & 8489 & 10,19 & 0,634 \\
& 1999 & 60,2 & 8632 & 9,68 & 0,711 \\
\hline
\end{tabular}

Źródło: opracowano na podstawie Emitora 1996-1999, CIE, ARE, Warszawa

Elektroenergetyka, mając na uwadze bliską perspektywę uruchomienia w Polsce konkurencyjnego rynku energii elektrycznej rozpoczęła na początku lat 90 . szeroki program inwestycji ekologicznych i modernizacyjnych. Jego celem jest sprostanie europejskim standardom w zakresie sprawności przemian energetycznych i poziomu emisji zanieczyszczeń. Ten bardzo kapitałochłonny program ekologicznego podźwignięcia i rekonstrukcji potencjału wytwórczego został podjęty dzięki kredytom bankowym uzyskanym przez elektrownie. Wiarygodność spłaty zaciągniętych pożyczek jest zagwarantowana przez długoterminowe kontrakty na dostawy energii elektrycznej jakie zawarły elektrownie z Polskimi Sie- 
ciami Elektroenergetycznymi S.A.. Takie rozwiązanie problemów finansowych elektrowni usztywniło rynek energii elektrycznej w Polsce i ograniczyło możliwości jej zakupu u tańszych producentów.

Na szeroki program transformacji ekologicznej elektroenergetyki składają się inwestycje związane $\mathrm{z}$ unowocześnieniem i rekonstrukcją turbozespołów, a także wymiana tradycyjnych kotłów na kotły fluidalne. Od 1997 r. w sektorze oddano do eksploatacji osiem kotłów fluidalnych w elektrociepłowniach: Żerań, Siekierki, Katowice, oraz w elektrowniach Jaworzno II, Turów i Siersza. Umożliwiają one znacząca redukcję dwutlenku siarki, w granicach 80-95\% i tlenków azotu, przeciętnie o $60 \%$. Kotły energetyczne wyposażono również $w$ palniki niskoemisyjne, skutecznie obniżające emisję tlenków azotu, przeciętnie od $40 \%$ do $50 \%$ (Gajda, Barc 1999).

Wśród działań zmierzających do sprostania wymogom ochrony środowiska obok poprawy jakości spalanego paliwa i modernizacji urządzeń produkcyjnych znalazły się także inwestycje "końca rury" polegające na wyposażaniu elektrowni w instalacje do odsiarczania spalin. Istnieje cały szereg rozwiązań technologicznych pochodzenia krajowego i zagranicznego, przy czym najbardziej skuteczny jest sposób mokrego odsiarczania spalin, przy użyciu jako sorbentu magnezu lub wapnia. Umożliwia on w około $95 \%$ redukcję emisji dwutlenku siarki, podczas gdy w mniej kapitałochłonnych instalacjach typu półsuchego i suchego sprawność odsiarczania spalin waha się w granicach 35-80\% (Gajda, Barc,1999). Właśnie w wysokosprawne instalacje mokrego odsiarczania spalin, o gwarantowanej emisji dwutlenku siarki $400 \mathrm{mg} / \mathrm{m}^{3}$, spełniające europejskie normy, zostały od $1996 \mathrm{r}$. stopniowo wyposażane największe krajowe elektrownie jak: Bełchatów, Kozienice, Dolna Odra, Połaniec, Opole, Jaworzno III, Laziska. Natomiast na instalacje o niższej sprawności działania, typu półsuchego i suchego zdecydowały się elektrownie: Turów, Rybnik, Łagisza, Siersza oraz elektrociepłownie warszawskie i poznańskie. W niektórych $\mathrm{z}$ nich dokonano również wymiany kotłów na fluidalne.

W świetle przeprowadzonej analizy można stwierdzić, że rozpoczęta w 1996 r. inwestycyjna faza procesu redukcji zanieczyszczeń gazowych przyniosła pozytywne skutki i jest nadal kontynuowana. W rezultacie, w stosunkowo krótkim czasie wystapiła kumulacja oddanych do użytku urządzeń ochrony środowiska. Do 1999 r. $69 \%$ mocy zainstalowanej w energetyce zawodowej (na $29327 \mathrm{MW}$ ) objęto ograniczeniami w emisji dwutlenku siarki. Tak więc program ekologicznej modernizacji elektroenergetyki w zakresie redukcji dwutlenku siarki powinien zostać pomyślnie zakończony w 2004 r., zgodnie z wcześniejszymi przewidywaniami.

Elektroenergetyka $\mathrm{z}$ tytułu prowadzonej głębokiej modernizacji poniosła ogromne nakłady inwestycyjne, rzędu $6 \mathrm{mld} \mathrm{zl}$, z tego aż $67 \%$ przeznaczono na urządzenia do odsiarczania spalin (Tabela 4).Następstwem poniesionych wydatków finansowych jest wzrost kosztów eksploatacji elektrowni. Wynosi on w przypadku elektrowni użytkujących zagraniczne instalacje odsiarczania spalin o około 5 USD/MWh, a dla elektrowni eksploatujących krajowe urządzenia do 3 USD/MWh (Gajda, Barc, 1999). Przełoży się to z pewnością na poziom cen energii elektrycznej dla odbiorców krajowych. 


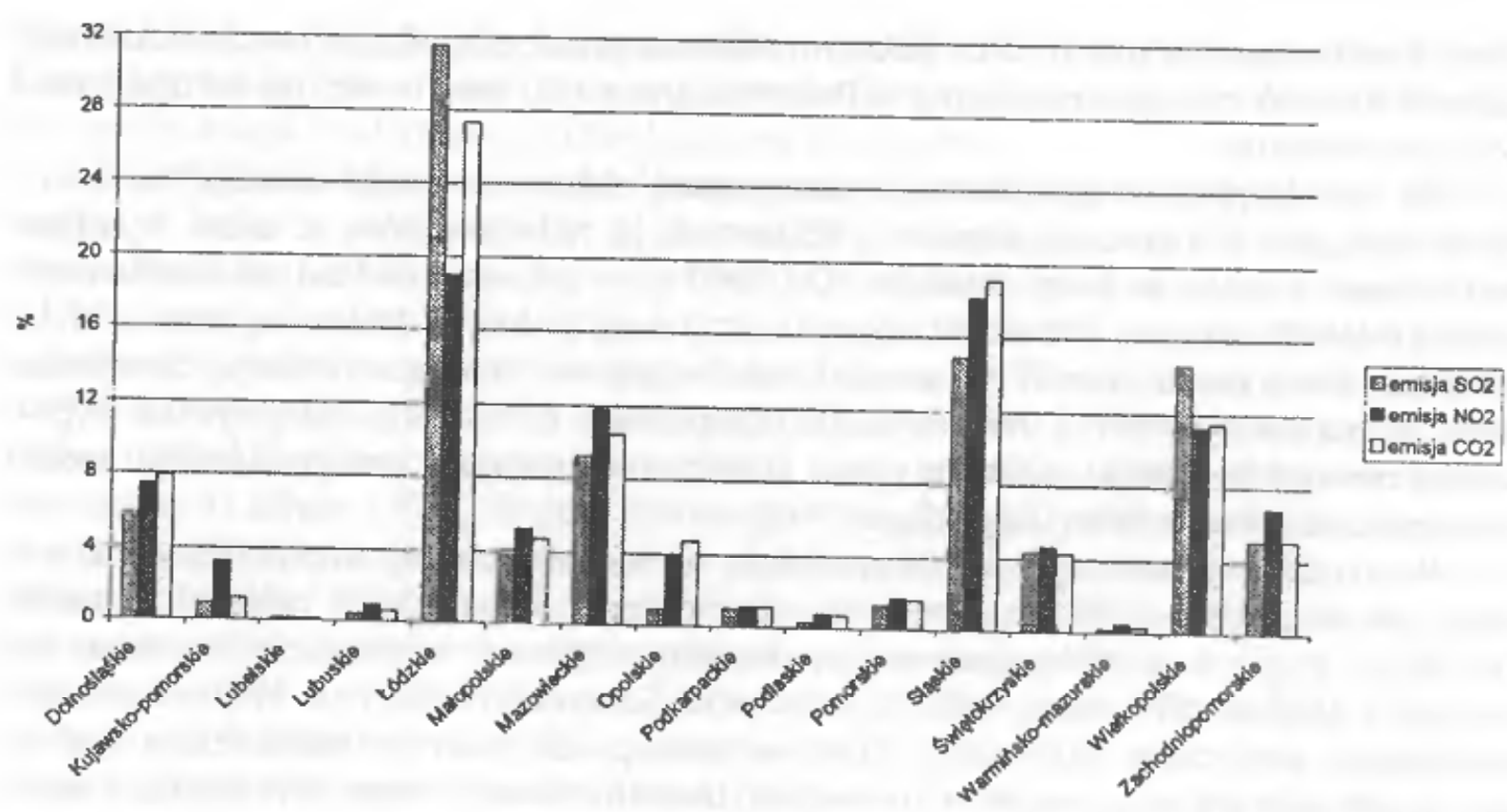

Źródło: Opracowano na podstawie Emitora 1999, ARE, W-wa

Ryc. 5. Emisja zanieczyszczeń gazowych z elektrowni zawodowych według województw z 1999 roku

Tabela 4. Struktura nakładów inwestycyjnych wydatkowanych przez elektrownie zawodowe w latach 1990-1999 na modernizację ekologiczną

\begin{tabular}{|l|c|c|}
\hline \multicolumn{1}{|c|}{ Wyszczególnienie } & \multicolumn{2}{|c|}{$\begin{array}{c}\text { Nakłady inwestycyjne } \\
\text { mln zl PLN \% }\end{array}$} \\
\hline Odpylanie & 1332 & 21,0 \\
Odsiarczanie & 4269 & $67, \mathrm{I}$ \\
Redukcja $\mathrm{NO}_{2}$ & 756 & 11,9 \\
\hline Razem & 6357 & 100,0 \\
\hline
\end{tabular}

Ceny porównywalne z $2000 \mathrm{r}$.

Źródło: Biuro Strategii i Rozwoju PSE, Warszawa

\section{Regionalne zróżnicowanie emisji zanieczyszczeń gazowych}

Rozkład przestrzenny emisji zanieczyszczeń gazowych w elektroenergetyce charakteryzuje się skrajnymi regionalnymi dysproporcjami wynikającymi z dużej koncentracji mocy w pojedynczych elektrowniach, rodzaju i jakości użytkowanych paliw stałych, efektywności procesu przemian energetycznych oraz stopnia wyposażenia $w$ urządzenia redukcji zanieczyszczeń gazowych (ryc. 5). Zdecydowaną dominację w tym zakresie wykazuje woj. łódzkie, na które w 1999 r. przypadało 31,5\% krajowej emisji dwutlenku siarki pochodzącej z elektroenergetyki, $19 \%$ dwutlenku azotu i $27,3 \%$ dwutlenku węgla. Sprawcą tej sytuacji jest zlokalizowana na jego obszarze największa w sektorze elektrownia Bełchatów (4320 MW mocy), której udział w krajowej produkcji energii elektrycznej utrzymuje się na 
poziomie $22 \%$. Na drugiej pozycji plasuje się woj. śląskie, z $14,9 \%$ udziałem udział w emisji dwutlenku siarki, 18,1\% dwutlenku azotu i $19 \%$ dwutlenku węgla. Generalnie na sześć województw tj.: łódzkie, śląskie, wielkopolskie, dolnośląskie, mazowieckie i zachodniopomorskie przypada aż $82 \%$ sumarycznej emisji dwutlenku siarki, $74 \%$ dwutlenku azotu i $81 \%$ dwutlenku węgla. Tak wysoka koncentracja emisji zanieczyszczeń gazowych ze stacjonarnych źródeł stanowi nadal ogromne obciążenie dla gospodarki, a jednocześnie wyzwanie dla polityki regionalnej tych obszarów.

Warto jeszcze przyjrzeć się zmianom jakie zaszły w rozkładzie przestrzennym emisji dwutlenku siarki w okresie 1989-1998, z uwzględnieniem poszczególnych elektrowni zawodowych (ryc. 6). Największa liczba elektrowni występuje na obszarze województwa śląskiego, ale sumaryczna wielkość ich emisji jest dwukrotnie mniejsza w stosunku do elektrowni Bełchatów. Na tym tle wyjątkowo korzystna jest sytuacja elektrowni Opole. której wszystkie turbozespoły $(4 \times 360 \mathrm{MW})$ współpracują z instalacjami mokrego odsiarczania spalin. Poprawa jakości spalanego węgla kamiennego oraz konsekwentna realizacja programu redukcji emisji dwutlenku siarki znacznie ograniczyła wielkość emisji, ale układ regionalny dysproporcji w tym zakresie nie uległ zmianie.

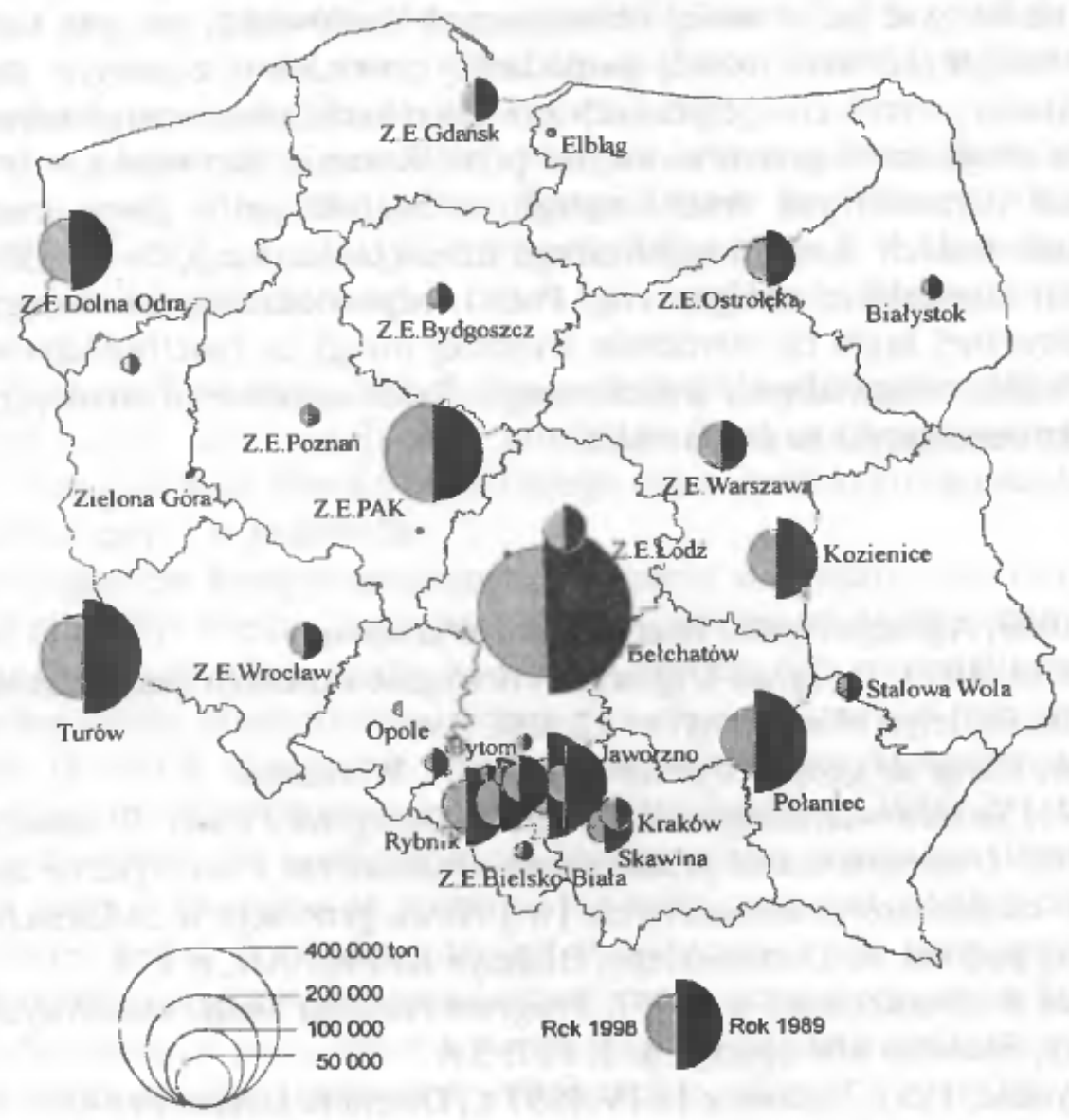

Źródło: opracowano na podstawie Statystyki Elektroenergetyki Polskiej 1990, CIE, Emitora 1998. ARE, W-wa

Ryc. 6. Emisja dwutlenku siarki w elektrowniach zawodowych w latach 1989 i 1998 
W procesie transformacji krajowego sektora elektroenergetyki zagadnienia ochrony środowiska znalazły właściwe uznanie i rangę. Usankcjonowane to zostało w nowym prawie energetycznym i w założeniach polityki energetycznej Polski do 2020 r. Realizacja programu modernizacji ekologicznej elektroenergetyki przyniosła pozytywne rezultaty w postaci skutecznego obniżenia ilości wyemitowanych zanieczyszczeń gazowych, a szczególnie dwutlenku siarki. Nie uzyskano natomiast efektów z tytułu ograniczenia emisji dwutlenku węgla.

W dłuższej perspektywie nie można jednak prognozować rozwoju elektroenergetyki bazującego na coraz ostrzejszych limitach emisji zanieczyszczeń. Stosowane dotychczas bezpośrednio w sposób nakazowy działania państwa niosą za sobą ryzyko przewymiarowania inwestycji ekologicznych, co niewątpliwie przełoży się na wyższe koszty i ceny energii elektrycznej. Dlatego też konieczne jest kompleksowe rozwiązanie problemu; wielkość i struktura produkcji energii elektrycznej a wpływ na środowisko. Tylko realizacja spójnego systemu zarządzania środowiskiem i energią umożliwi określenie skali redukcji zanieczyszczeń niezbędnych do przeprowadzenia w elektroenergetyce.

Kluczowe znaczenie dla dalszego, skutecznego obniżenia zanieczyszczeń gazowych w elektroenergetyce, a szczególnie dwutlenku węgla, będzie miała dywersyfikacja struktury paliwowej na korzyść paliw mniej obciążających środowisko, jak gaz ziemny i odnawialne źródła energii. Lokalny rozwój gospodarczy powinien w znacznym stopniu korzystać w zaspokajaniu potrzeb energetycznych z miejscowych źródeł energii odnawialnej.

Zgodnie z prognozami przedstawionymi przez Komisję Europejską w tzw. „Zielonej Księdze" udział odnawialnych źródeł energii w bilansie paliw pierwotnych wzrośnie w krajach członkowskich w ciagu najbliższego dziesięciolecia z 5,5\% do $12 \%$. Powyższe stanowisko Unii Europejskiej obliguje rząd Polski, odpowiedzialny za strategiczny kształt polityki energetycznej kraju do zwrócenia większej uwagi na możliwości i warunki rozwoju wykorzystania odnawialnych źródeł energii. Takie stanowisko zmniejszy równocześnie presję elektroenergetyki na środowisko.

\section{Literatura}

Emitor, 1994-1999, Agencja Rynku Energii S.A., Warszawa.

Gajda A., Barc W, 1999, Przegląd krajowych rozwiqzań instalacji odsiarczañia i odazotowania spalin, Biuletyn Miesięczny, nr 12, PSE S.A.

Kortus B., 1986, Wstep do geografii przemyslu, PWN, Warszawa.

Luchter L., 1995, Strukturwandlungen in der Elektroenergetik Polens, Weimar, Dadder.

Luchter L., 1996, Uwarunkowania przestrzenno-ekonomiczne i ekologiczne dostaw wegla kamiennego do elektrowni zawodowych, [w:] Nowa generacja w badaniach gospodarki przestrzennej pod red. R. Domańskiego, Biuletyn KPZK PAN, z. 174.

Poręba S., Gajda A., Burakowski A., 1997, Program redukcji emisji szkodliwych substancji do atmosfery, Biuletyn Miesięczny, nr 3, PSE S.A.

Prawo Energetyczne, 1997, Ustawa z 10.IV.1997 r., Dziennik Ustaw, nr 54/9.

Statystyka Elektroenergetyki Polskiej, 1990-1999, Agencja Rynku Energii S.A. Warszawa.

Wieloński A., 2000, Geografia przemystu, PWN, Warszawa.

Wykaz standardów dopuszczalnej emisji obowiązujących w krajach rozwiniętych, 1994, Centrum Informatyki Energetyki, Warszawa. 